\title{
Investigating the Mediator role of Social Safeness on the Relationship between Forgiveness and Life Satisfaction
}

\author{
Umran Akin* and Ahmet Akin
}

Sakarya University, Faculty of Education, Department of Psychological Counselling and Guidance, Sakarya (Turkey).

\begin{abstract}
Título: Investigando el papel mediador de la seguridad en lo social en la relación entre el perdón y la satisfacción por la vida.

Resumen: El propósito de este estudio consiste en investigar el efecto mediador de la seguridad en lo social sobre la relación entre la satisfacción por la vida y el perdón. Los participantes son 311 alumnos de universidad que completaron una encuesta que incluye la Escala de Rasgos Caritativos, la Escala de Seguridad y Placer en lo social y la Escala de Satisfacción por la vida. Según los resultados, la satisfacción por la vida y la satisfacción por la vida fueron positivamente predichos por la seguridad en lo social. Por otro lado, la satisfacción por la vida se predijo positivamente por la seguridad en lo social. Además la seguridad en lo social medió en la relación entre perdón y satisfacción por la vida. Los resultados se discutten a la luz de la literatura relacionada y se dan recomendaciones sobre esta área.

Palabras clave: Seguridad en lo social; satisfacción por la vida; perdón; caridad; análisis de regresión jerárquica.
\end{abstract}

\section{Introduction}

For a human being, one of the most important developmental tasks is to create and maintain close, enduring, and satisfying relationships. In other words, individuals are motivated to remain in relationship with others (relatedness) and the quality of these interpersonal relations is crucial to personality and social development (Blatt \& Blass, 1996). However, in addition to the motivation of individuals to stay together, there are also possibilities of encountering some hurtful events and situations (Fincham, 2000). In the aftermath of a hurtful event, people experience negative emotions such as anger, resentment, and disappointment and these emotions cause avoidance or vengeance. On the contrary of the avoidance or feeling of vengeance there is an individual's motive to continue being linked to others. This motive was called as forgiveness which has an important role in the coping of such negative emotions (McCullough et al., 1998).

Through the human history, forgiveness has been considered as a key factor to repair offending behaviors and negative situations experienced in interpersonal relationships (Hargrave \& Sells, 1997). By leaving aside the fight with the person and incident that unjustly hurt them, forgiving people are willingness to forego anger and their rights to judge the offending person and to act in the same way to that person. Forgiveness is a process to try to sense feelings toward the offending person that they do not deserve such as compassion, generosity, and love, and is an unconditional situation related to acceptance that offended person offers to the offending person (Enright \& Fitzgibbons, 2000).

* Dirección para correspondencia [Correspondence address]:

Umran AKIN. Sakarya University, Faculty of Education 54300 Hendek,

Sakarya (Turkey). E-mail: uakin@sakarya.edu.tr
Abstract: The aim of the present study is to examine the mediating effect of social safeness on the relationship between forgiveness and life satisfaction. Participants were 311 university students who completed a questionnaire package that included the Trait Forgiveness Scale, the Social Safeness and Pleasure Scale, and the Life Satisfaction Scale. According to the results, social safeness and life satisfaction were predicted positively by forgiveness. On the other hand, life satisfaction was predicted positively by social safeness. In addition, social safeness mediated on the relationship between forgiveness and life satisfaction. The results were discussed in the light of the related literature and dependent recommendations to the area were given. Key words: Forgiveness; social safeness; life satisfaction; hierarchical regression analysis.

Forgiveness has been defined by Hargrave and Sells (1997) as an individual's permission to reinstate trust in the relationship even though the person was subjected to hurtful behavior and the ability of both offending and offended individuals to discuss this hurtful behavior to improve their relationship. The basic motives underlying forgiveness are diminished revenge and avoidance with increased benevolence and good will towards the person committed the offense (McCullough, Worthington, \& Rachal, 1997). Forgiveness is also based on the change in the motives of revenge, avoidance from the offending person, and kindness toward that person that emerges when the individual is offended.

To forgive somebody's offence, it is required to replace the sense of vengeance of the offended person with feelings of tolerance and empathy in order to improve the damaged relationship. Nonetheless forgiveness does not require the denial of past errors and covering of errors and the process forgiveness is neither the ignoring of unfairness nor transformation of justice into revenge (Rodden, 2003). Researchers have suggested that forgiveness should be differentiated from condoning, excusing, pardoning, forgetting and that forgiveness is distinct from reconciliation (McCullough, 2000).

In various studies, forgiveness has been found positively related to empathy, general religiousness (Tsang \& Stanford, 2006), gratitude (McCullough, Emmons, \& Tsang, 2002), positive affect (Maltby, Day, \& Barber, 2004), hope, selfesteem, reduced anxiety, and low level depression (AlMabuk, Enright, \& Cardis, 1995; Freedman \& Enright, 1996; Hebl \& Enright, 1993; Karremans, Van Lange, Ouwerkerk, \& Kluwer, 2003; Maltby, Macaskill, \& Day, 2001;). It also has been shown to has negative relationships with anger rumination, thoughts of revenge (Barber, Maltby, \& Macaskill, 2005), and neuroticism (Maltby, et al., 2001; Walker \& Gorsuch, 2002). Similarly, when compared with unforgiving in- 
dividuals, forgiving individuals were found to have better well-being (Karremans et al., 2003).

\section{Social safeness}

Social safeness was defined as people's experiences and perceptions about their social world as safe, warm, and soothing which are related feelings of belonging and acceptance from others (Gilbert et al., 2009). It differs from both need to belong in that social safeness is considered an emotional experience, while the need to belong mostly viewed as a motivational construct (Baumeister \& Leary 1995; Kelly, Zuroff, Leybman, \& Gilbert, 2012) and from social support since the social support has been perceived mostly as a cognitive construct (Kelly et al., 2012). On the other hand social safeness does share some similar properties with both social support and need to belong and therefore people who perceived high levels of sense of social support and who are fulfilled in their need to belong would also have elevated levels of social safeness (Kelly et al., 2012). Regarding to, social safeness plays a positive and facilitative role on the well-being of individuals (Kelly et al., 2012). Individuals with higher level of sense of social safeness tend to think creatively, manage problems more effectively, and act in a more pro-social manner. In contrary people who have difficulty in accessing social safeness are more vulnerable to psychological problems because they are fearful of compassion from others (Gilbert, 2005; Gilbert et al., 2009).

People who consider other people in their society as trustful and who have sense of safe about their social life are also have more optimistic thoughts about their own power to change their life and tend to be happier with how their life is going (Rothstein \& Uslaner, 2005). However individuals who feel socially insecure have problems involving in social activities, have restricted social lives, and have more tendencies to use Internet frequently (Griffiths, 2000). Studies indicated that sense of social safeness is positively related to self-esteem and secure attachment (Kelly et al., 2012). Social safeness was found on the other hand related negatively to depression, anxiety, hostility, self-criticism, preoccupied, fearful, and dismissing attachment, paranoid traits, borderline traits (Gilbert, 2010; Kelly et al., 2012), submissive behavior, shame, and feelings of inferiority (Gilbert 2010).

\section{Life satisfaction}

Life satisfaction, a cognitive appraisal of one's life quality and depends on one's cognitive and subjective evaluation (Gilman \& Huebner, 2003), has considered as an important measure for psychological health and subjective well-being and (Pavot \& Diener, 2008). Life satisfaction was described by Frisch (2000) as "excellence or goodness in aspects of life that go beyond mere subsistence, survival, and longevity" ( $p$. 208). It also shows the extent to how much people's life is satisfying their physical and psychological desires (Demerou- ti, Bakker, Nachreiner, \& Schaufeli, 2000). These desires can be reflected in many different aspects of life such as friends, work, family, and school (Rostami \& Abedi, 2012).

Studies have shown that life satisfaction plays a buffer role against the development of psychopathology (Suldo \& Huebner, 2004) and people with high level of life satisfaction are less likely to experience psychological and physical symptoms (Siahpush, Spittal, \& Singh, 2008). In these studies life satisfaction was found positively related to happiness, optimism (Sapmaz \& Doğan, 2012), marital adjustment (Çelik \& Tümkaya, 2012), self-esteem (Yiğit, 2012), emotional intelligence (Palmer, Walls, Burgess, \& Stough, 2001), perceived social support (Edwards \& Lopez 2006), hope (Bailey et al., 2007), positive affectivity (Busseri et al., 2007), ego strength, and positivism (Diener, Napa-Scollon, Oishi, Dzoketo, \& Suh, 2000). Life satisfaction was negatively associated with loneliness (Goodwin, Cook, \& Yung, 2001), automatic thoughts (Bulut, 2007), perceived stress (Extremera et al., 2009), and depression (Wong \& Lim, 2009).

\section{Social Safeness as a Mediator}

Forgiveness is a human strength and represents positive psychological responses to interpersonal harms and promotes social relationships (Bono \& McCullough, 2006). Forgiveness also contributes to well-being mainly from its potential to help people maintain supportive safe and close relationships (Karremans et al., 2003). In addition, forgiveness is positively related to some adaptive constructs such as optimistic thinking, self-efficacy, and especially social support (Thoresen, Harris, \& Luskin, 2000). Results of these studies have generally demonstrated the positive associations of forgiveness with adaptive academic outcomes. What remains uncertain is whether common social processes underlie these relations; and, no study has systematically investigated mediators of the association between forgiveness and life satisfaction. To fully understand which factors contribute to development of forgiveness, it must be well-understood how and why forgiveness might impact social safeness and life satisfaction. Thus, in the current study it was proposed to test the role of social safeness in mediating the effect of forgiveness on life satisfaction.

Social safeness may well be one of the variables which mediate the relationship between forgiveness and life satisfaction for several reasons: First of all, social safeness is positively correlated with self-esteem and negatively with selfcriticism (Kelly et al., 2012) and therefore decreases vengeful thinking and increases forgiveness because vengeful cognitions are related to restoring self-worth (Cota-Mckinley et al., 2001) and these cognitions might be motivated by the goal of saving face (Mccullough et al., 2001). Second, individuals with feelings of social safeness were less likely to be fearful and insecure in their attachment style which may be related to under-activation of the soothing-affiliation system (Gilbert, 2005; Kelly et al., 2012; Liotti, 2000). Thus, people who are calm (in other words, whose soothing-affiliation 
system is active) have not hostile attribution style and are more likely to forgive somebody's offence (Bies \& Tripp, 2005; Tripp et al., 2002). Third social safeness was found negatively associated with paranoid tendencies that include being skeptical of others' intentions and monitoring others' behavior with suspicion (Kelly et al., 2012), and ultimately aspiring to "teach the so-called enemy a lesson". Thus people with social safeness view others' attitudes and behaviors with openness and trust (Kelly et al., 2012) and thereby increase the possibility of forgiveness. Also, reduced distress and increased life satisfaction may be a byproduct of social safeness which is characterized by feelings of warmth, connectedness, and contentment (Kelly et al., 2012). Taken together, these suggestions indicate that social safeness may be a key process underlying the relationships between forgiveness and life satisfaction. Therefore, people with higher level of forgiveness may also have lower level of social safeness. This may be partly due to the fact that people with high levels of sense of forgiveness may easily establish close relationships which allows them to feel high levels sense of life satisfaction.

Considering the studies demonstrating the relationships of forgiveness, social safeness, and life satisfaction with indices of psychological, social, and cognitive well-being, it seems possible that social safeness may be enhanced by forgiveness and thus it also may help to improve life satisfaction. In the light of the reciprocal relationships between forgiveness, social safeness, and life satisfaction with other variables that have been demonstrated by previous research, forgiveness may influence to life satisfaction via social safeness. The purpose of current research is to investigate the mediating effect of social safeness as well as the associations of forgiveness, social safeness, and life satisfaction. In this study it was hypothesized that forgiveness would positively associate with social safeness and with life satisfaction and social safeness would be positively related to life satisfaction. It was also expected that social safeness would mediate the link between forgiveness and life satisfaction.

\section{Method}

\section{Participants}

The participants were 311 university students (171 (55\%) were female and $140(45 \%)$ were male) enrolled in various undergraduate programs at a mid-size state university, Turkey. Their ages ranged from 18 to 26 and GPA scores ranged from 1.99 to 3.73 . Of the participants, $90(29 \%)$ were first-year students, $87(28 \%)$ were second-year students, 99 $(32 \%)$ were third- year students, and $35(11 \%)$ were fourthyear students.

\section{Measures}

Trait Forgiveness Scale Berry, Worthington, Parrott, \& Wade, 2005). The scale consist of ten items (e.g., I can forgive a friend for almost anything) and each items ranging from 1 (strongly disagree) to 5 (strongly agree). Yield total scores from 10 to 50 where higher scores indicate more forgiveness level. Turkish adaptation of this scale had been done by Akın, Akın, and Gediksiz (2012). The results of confirmatory factor analysis indicated that the model was well fit $\left(x^{2}=\right.$ 106.47, $\mathrm{df}=32, x^{2} / \mathrm{df}=3,327, p<.05$, RMSEA $=.077$, CFI $=$ $.89, \mathrm{GFI}=.95, \mathrm{AGFI}=.91$, and $\mathrm{SRMR}=.062)$. Factor load ings ranged from .29 to .67 . The internal consistency coefficient of the scale was .67 and the corrected item-total correlations ranged from .26 to .43 .

The Social Safeness and Pleasure Scale (SSPS, Gilbert et al., 2009). The SSPS was used to measure social safeness. It was developed to assess the extent to which individuals feel a sense of warmth, acceptance, and connectedness in their social world (Gilbert et al., 2009). Participants rate their agreement with 11 statements (e.g., I have a sense of being cared about in the world) using a Likert scale from 1 ("almost never") to 5 ("almost all the time"). The Cronbach alpha coefficient of the original form was .91. Turkish adaptation of this scale had been done by Akın, Uysal and Çitemel (2013). To assess construct validity confirmatory factor analysis was utilized and this analysis indicated that the unidimensional model was well fit. The goodness of fit index values of the model were $x^{2}=71.82, \mathrm{df}=40, x^{2} / \mathrm{df}=1,795, p$ $<.05, \mathrm{RMSEA}=.048, \mathrm{NFI}=.96, \mathrm{CFI}=.98, \mathrm{IFI}=.98, \mathrm{RFI}=$ $.95, \mathrm{GFI}=.96$, and $\mathrm{SRMR}=.042$. The overall internal consistency reliability coefficient of the scale was .82 . The corrected item-total correlations of SSPS ranged from .34 to .61 .

The Satisfaction with Life Scale (SWLS, Diener, Emmons, Larsen, \& Griffin, 1985). The SWLS consists of five items (e.g., In most ways my life is close to my ideal) using a Likert scale from 1 (strongly disagree) to 7 (strongly agree). A sum of all scores yields a total score that ranges from 5 to 35; a higher score indicates a higher life satisfaction level. Turkish adaptation of this scale had been done by Durak, SenolDurak, and Gencoz (2010). They found that internal consistency coefficient was .81 and the corrected item total correlations ranged from .55 to .63 . Results of confirmatory factor analysis indicated that the model was well fit. The goodness of fit index values of the model were $x^{2} / \mathrm{df}=2.026, \mathrm{p}=$ $.072, \mathrm{IFI}=.994, \mathrm{TLI}=.987, \mathrm{CFI}=.994, \mathrm{SRMR}=.020$, and RMSEA $=.043$.

\section{Procedure}

Firstly permission for administration of the scales to the participants was obtained from related chief departments. Than participants were informed of the purpose and of the voluntary nature of study and were ensured anonymity for all responses given. Self-report questionnaires were administered in a quiet classroom setting and the scales were administered to the students in groups in the classrooms. To determine the relationships among forgiveness, social safeness, and life satisfaction; the Pearson correlation coefficient and 
regression analyses were used. In order to test whether social safeness mediated the link between forgiveness and life satisfaction with regression analyses, Baron and Kenny's (1986) recommendations were followed. These analyses were carried out via SPSS 13.0.

\section{Data Analysis}

To determine the relationships among forgiveness, social safeness, and life satisfaction; the Pearson correlation coefficient and hierarchical regression analyses were used. In order to test whether social safeness mediated the link between forgiveness and life satisfaction with hierarchical regression analyses, Baron and Kenny's (1986) recommendations were followed. These analyses were carried out via SPSS 13.0.

\section{Results}

\section{Descriptive Data and Inter-correlations}

Table 1 shows the means, descriptive statistics, intercorrelations, and internal consistency coefficients of the variables used.

Table 1. Descriptive Statistics and Inter-correlations of the Variables.

\begin{tabular}{lccc}
\multicolumn{4}{l}{ Table 1. Descriptive Statistics and Inter-correlations of the Variables. } \\
\hline Variables & 1 & 2 & 3 \\
\hline 1. Forgiveness & 1.00 & & \\
2. Social Safeness & $.49^{* *}$ & 1.00 & \\
3. Life Satisfaction & $.39^{* *}$ & $.55^{* *}$ & 1.00 \\
Mean & 32.08 & 31.97 & 23.29 \\
Standard deviation & 6.84 & 7.69 & 6.73 \\
${ }^{* *} p<.01$ & & &
\end{tabular}

When Table 1 is examined, it is seen that there are significant correlations between forgiveness, social safeness, and life satisfaction. Forgiveness related positively to social safeness $(r=.49)$ and to life satisfaction $(r=.39)$. On the other hand, social safeness was found to be positively $(r=.55)$ related to life satisfaction.

Testing the Mediating Role of Social Safeness in the Relationship between Forgiveness and Life Satisfaction

Following the steps of the mediation procedure, firstly it was verified that forgiveness and social safeness were positively related $(\beta=.49, t=9.785, p<.001,95 \% C I=.44, .66$, $\left.R^{2}=.24\right)$. Then it was verified that social safeness and life satisfaction revealed a positive relationship $(\beta=.55, t=$ 5.698, $\left.p<.001,95 \% \mathrm{CI}=.41, .57, \mathrm{R}^{2}=.31\right)$. To test the third and last steps of mediation procedure, regression analysis was done. The results of the regression analysis demonstrated that forgiveness was positively associated with life satisfaction $(\beta=.39, t=7.333, p<.001,95 \% C I=.28, .48$, $\left.R^{2}=.15\right)$. However, when social safeness and forgiveness were taken together in the regression analysis, the signifi- cance of the relationship between forgiveness and life satisfaction $\left(\beta=.15 t=2.823, p<.01,95 \% C I=.33, .51, \mathrm{R}^{2}=\right.$ .33) decreased, yet the relationship between forgiveness and life satisfaction was significant. According to Baron and Kenny (1986), this result indicated a partial mediation. Therefore, it can be said that social safeness partially explains the relationship between forgiveness and life satisfaction. The results are presented in Figure 1.

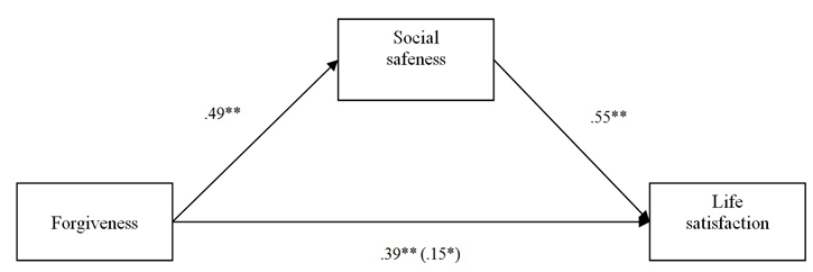

Figure 1. Standardized regression coefficients for the relationship between forgiveness and life satisfaction as mediated by social safeness. The standardized regression coefficient between forgiveness and life satisfaction, controlling for social safeness, is in parentheses. $* * p<.001, * p<.01$

The present model was tested using the Sobel $z$ test (Sobel, 1982). The purpose of this test is to verify whether a mediator carries the influence of an interdependent variable to a dependent variable. The Sobel $z$ test is characterized as being a restrictive test, and as such, assures that the verified results are not derived from collinearity issues. In the present study, the test value verified was $Z=7.30 ; p=<.0001$.

\section{Discussion}

The purpose of this research was to investigate the relationships between forgiveness social safeness, and life satisfaction. Results indicated that there are significant relationships between these variables. As expected, results indicated that the relationship between forgiveness and life satisfaction was partially mediated by social safeness. In other words, as forgiveness increases in this model, satisfaction with life also increases and social safeness plays a mediating role in that increase. This result is important for several reasons. The study suggests the importance of social safeness among positive relational characteristics. If individuals feel more themselves with safe in their social world, they may have more feelings of life satisfaction. In having more positive emotional feelings toward other people, forgiveness may be associated with viewing the wrongdoer with compassion instead of seeking revenge and experiencing interpersonal conflict. And thus people with high level of forgiveness see other individuals and their social environment as less threatening and thus feel themselves in a safer world.

In addition, some details of the results should be further addressed. First as hypothesized, forgiveness has positively predicted social safeness. Individuals with sense of social safeness manage their problems more effectively, participate 
in social activities more easily, act in a pro-social manner, and have more optimistic thoughts about their power to change their life (Rothstein \& Uslaner, 2005). Similarly since forgiveness is another positive characteristic that reduces motivation to seek revenge or to avoid the transgressor and increases compassion or sympathy (McCullough et al., 1998) it is also vital for maintenance of close relationships and is viewed as necessary for satisfying and lasting relationships (Lambert, Fincham, Stillman, Graham, \& Beach, 2009). Also studies showed that both forgiveness and social safeness are positively related to same mental health indicators such as lower depression and anxiety (Gilbert, 2010; Kelly et al., 2012), positive affect, self-esteem (Karremans et al., 2003; Kelly et al., 2012; Maltby et al., 2004). Therefore and consistent with the results of the present study, it appears that greater forgiveness is positively linked to social safeness.

Secondly, as anticipated, life satisfaction was positively influenced by social safeness. As life satisfaction is related to happiness, optimism (Sapmaz \& Doğan, 2012), hope (Bailey et al., 2007), self-esteem (Yiğit, 2012), positive affectivity (Busseri et al., 2007), perceived social support (Edwards \& Lopez 2006), positivism (Diener et al., 2000), lower loneliness (Goodwin et al., 2001), diminished perceived stress (Extremera et al., 2009) and depression (Wong \& Lim, 2009) and social safeness related to a plethora of adaptive variables that given above, the positive association of social safeness with life satisfaction seems very reasonable. Therefore it appears that if individuals have a positive family and social environment which contribute to and enhance their sense of social safeness, then they may increase their satisfaction with life level.

Thirdly, social safeness partially mediated the relationship between forgiveness and life satisfaction. This result extends what is known about forgiveness and its link to life satisfaction. Although studies have indicated that forgiveness can substantially influence life satisfaction, no research has addressed factors that might mediate these relationships. In other words, literature is unclear about in which direction a

\section{References}

Akın, A., Akın, U., \& Gediksiz, E. (2012). The validity and reliability of the Turkish version of the Forgivingness Scale. Paper presented at the International Counseling and Education Conference 2012 (ICEC 2012), May, 3-5, İstanbul, Turkey.

Akın, A., Uysal, R., \& Çitemel, N. (2013). The validity and reliability of the Turkish version of the Social Safeness and Pleasure Scale (SSPS). Mersin University Journal of Faculty of Education, 9(1), 34-40.

Al-Mabuk, R. H., Enright, R. D., \& Cardis, P. A. (1995). Forgiveness education with parentally love-deprived late adolescents. Journal of Moral Education, 24, 427- 444

Bailey, T. C., Eng, W., Frisch, M. B, \& Snyder, C. R. (2007). Hope and optimism as related to life satisfaction. The Journal of Positive Psychology: Dedicated to furthering research and promoting good practice, 2(3), 168-175. doi: 10.1080/17439760701409546.

Barber, L., Maltby, J., \& Macaskill, A. (2005). Angry memories and thoughts of revenge: the relationship between forgiveness and anger rumination. Personality and Individual Differences, 39, 253-262. Doi: http://dx.doi.org/10.1016/j.paid.2005.01.006. social variable relates with forgiveness. The results of this study are particularly interesting because it suggested that forgiveness influences life satisfaction through social safeness.

Limitations of the study should be acknowledged. First of all, perhaps the most important limitation is that the results obtained in this study should not be generalized neither to all university students nor to other student populations, since the data were collected at just one university. Although this sample allowed for greater freedom from volunteer selection, it also constrained the variability of participant characteristics, including age, socio-economic status, and education level. Therefore further study is required to assess the relationships between forgiveness, social safeness, and life satisfaction that targeting other student populations to generate more solid relationships among the constructs examined in this study. Secondly, as correlational statistics were utilized, no definitive statements can be made about causality. Third, the data reported here for forgiveness, social safeness, and life satisfaction are limited to self-reported data and did not use a qualitative measure of these variables. And last Cronbach alphas' were low for especially Forgiveness Scale, however they were acceptable in behavioral science.

In conclusion, this investigation shows that forgiveness affects social safeness directly and life satisfaction both directly and indirectly via social safeness. People who have higher level of forgiveness are more likely to be high in life satisfaction and in social safeness. The results also suggest that forgiveness plays a key role in supporting well-being. Hence, the current findings contribute to our understanding of the relationships between forgiveness, social safeness, and life satisfaction. Mental health professionals may develop research to assess the effectiveness of forgiveness improvement programs to help university students to increase social safeness, to have better mental health, and ultimately to increase satisfaction with life.

Baumeister, R. F., \& Leary, M. R. (1995). The need to belong: Desire for interpersonal attachments as a fundamental human motivation. Psychologi cal Bulletin, 117, 497-529.

Berry, J. W., Worthington, E. L., Jr., O’Connor, L., Parrott, L., \& Wade, N. G. (2005). Forgiveness, vengeful rumination, and affective traits. Journal of Personality, 73(1), 183-226. Doi: 10.1111/j.1467-6494.2004.00308.x.

Baron, R. M., \& Kenny, D. A. (1986). Moderator-mediator variables distinction in social psychological research: Conceptual, strategic, and statistical considerations. Journal of Personality and Social Psychology, 6, 1173-1182.

Bies, R. J., \& Tripp, T. M. (2005). The study of revenge in the workplace: Conceptual, ideological, and empirical issues. In S. Fox \& P. E. Spector (Eds.), Counterproductive work behaviour: Investigations of actors and targets, 6581. Washington, DC: American Psychological Association.

Blatt, S. J., \& Blass, R. B. (1996). Relatedness and self definition: A dialectic model of personality development. In G. G. Noam, \& K. W. Fischer (Eds.), Development and vulnerabilities in close relationships (pp. 309-338). Mahwah, NJ: Erlbaum. 
Bono, G., \& McCullough M. E. (2006). Positive responses to benefit and harm: Bringing forgiveness and gratitude into cognitive psychotherapy. Journal of Cognitive Psychotherapy, 20, 147-158. doi: http://dx.doi.org/10.1891/jcop.20.2.147.

Bulut, N. (2007). Relations between school psychological counselors' life satisfaction, strategies of coping with stress and negative automatic thoughts. Turkish Psychological Counseling and Guidance Journal, 3(27), 1-13.

Busseri, M. A., Sadava, S. W., \& Decourville, N. (2007). A hybrid model for research on subjective wellbeing: Examining common- and componentspecific sources of variance in life satisfaction, positive affect, and negative affect. Social Indicators Research, 83, 413-445. doi: http://dx.doi.org/10.1007/s11205-006-9028-8.

Cota-Mckinley, A. L., Woody, W. D., \& Bell, P. A. (2001). Vengeance: Effects of gender, age, and religious background. Aggressive Behavior, 27, 343-350. doi: 10.1002/ab.1019.

Celik, M. \& Tümkaya, S. (2012). The relationship between job variables of life satisfaction and marital satisfaction of lecturers. KEFAD, 13(1), 223-238.

Demerouti, E., Bakker, A. B., Nachreiner, F., \& Schaufeli, W. B. (2000). A model of burnout and life satisfaction among nurses. Journal of Advanced Nursing, 32, 454-464. doi: 10.1046/j.1365-2648.2000.01496.x.

Diener, E., Emmons, R. A., Larsen, R. J., \& Griffin, S. (1985). The satisfaction with life scale. Journal of Personality Assessment, 49, 71-75.

Diener, E., Napa-Scollon, C. K., Oishi, S., Dzoketo, V., \& Suh, E. M. (2000). Positivity and the construction of life satisfaction judgments: Global happiness is not the sum of its part. Journal of Happiness, 1, 159176. doi: 10.1023/A:1010031813405.

Durak, M., Senol-Durak, E., \& Gencoz, T. (2010). Psychometric properties of the satisfaction with life scale among Turkish university students, correctional officers, and elderly adults. Social Indicators Research, 99(3), 413-429. doi: 10.1007/s11205-010-9589-4.

Enright, R. D. \& Fitzgibbons, R. (2000). Helping clients forgive: An empirical guide for resolving anger and restoring hope. Washington, DC: APA Books.

Edwards, L. M., \& Lopez, S. J. (2006). Perceived family support, acculturation, and life satisfaction in Mexican American youth: A mixedmethods exploration. Journal of Counseling Psychology, 53(3), 279-287. doi: http://dx.doi.org/10.1037/0022-0167.53.3.279.

Extremera, N., Duran, A., \& Rey, L. (2009). The moderating effect of trait meta-mood on perceived stres on life satisfaction. Personality and Individual Differences, 47, 116-141. doi: 10.1016/j.paid.2009.02.007.

Fincham, F. D. (2000). The kiss of the porcupines: From attributing responsibility to forgiving. Personal Relationships, 7, 1-23.

Freedman, S. R., \& Enright, R. D. (1996). Forgiveness as an intervention goal with incest survivors. Journal of Consulting and Clinical Psychology, 64, 983-992.

Frisch, M. B. (2000). Improving mental and physical health care through quality of life therapy and assessment. In E. Diener \& D. R. Rahtz (Eds.), Advances in quality of life: Theory and research (pp. 207-241). London: Kluwer.

Gilbert, P. (2005). Compassion: Conceptualizations research and use in psychotherapy. Brunner-Routledge, London.

Gilbert, P. (2010). Compassion focused therapy. New York: Routledge.

Gilbert, P., McEwan, K., Mitra, R., Richter, A., Franks, L., Mills, A., Bellew, R., \& Gale, C. (2009). An exploration of different types of positive affect in students and patients with bipolar disorder. Clinical Neuropsychiatry, 6(4), 135-143.

Gilman, R., \& Huebner, E. S. (2003). A review of life satisfaction research with children and adolescents. School Psychology Quarterly, 18, 192-205.

Goodwin, R., Cook, O., \& Yung, Y. (2001). Loneliness and life satisfaction among three cultural groups. Personal Relationships, 8, 225-230. doi: 10.1111/j.1475-6811.2001.tb00037.x.

Griffiths, M. D. (2000). Does internet and computer "addiction" exist? Some case study evidence. Cyberpsychology and Behavior, 3, 211-218. doi:10.1089/109493100316067.

Hargrave, T. D., \& Sells, J. N. (1997). The development of a Forgiveness Scale. Journal of Marital and Family Therapy, 23(1), 41-62. doi: 10.1111/j.1752-0606.1997.tb00230.x.

Hebl, J. H., \& Enright, R. D. (1993). Forgiveness as a psychotherapeutic goal with elderly females. Psychotherapy, 30, 658-667.
Karremans, J. C., Van Lange, P. A. M., Ouwerkerk, J. W., \& Kluwer, E. S. (2003). When forgiveness enhances psychological well-being: The influence of interpersonal commitment. Journal of Personality and Social Psychology, 84, 1011-1026. doi: 10.1037/0022-3514.84.5.1011.

Kelly, A. C., Zuroff, D. C., Leybman, M. J., \& Gilpert, P. (2012). Social safeness, received social support, and maladjustment: Testing a tripartite model of affect regulation. Cognitive Therapy and Research, 36(6), 815-826. doi: 10.1007/s10608-011-9432-5.

Lambert, M. N., Fincham, F. D., Stillman, T. F., Graham, M. S., \& Beach, B. R. S. (2009). Motivating change in relationships: can prayer increase forgiveness? Psychological Science, 1-7. doi: 10.1177/0956797609355634.

Liotti, G. (2000). Disorganized attachment, models of borderline states, and evolutionary psychotherapy. In P. Gilbert, K. Bailey (Eds.), Genes on the couch: Essays in evolutionary psychotherapy. Hove: Psychology Press.

Maltby, J., Day, L., \& Barber, L. (2004). Forgiveness and mental health variables: Interpreting the relationship using an adaptational-continuum model of personalityand coping. Personality and Individual Differences, 37 , 1629-1641. doi: 10.1016/j.paid.2004.02.017.

Maltby, J., Macaskill, A., \& Day, L. (2001). Failure to forgive self and others: a replication and extension of the relationship between forgiveness, personality, social desirability, and general health. Personality and Individual Differences, 30, 881-885.

McCullough, M. E. (2000). Forgiveness as human strength: Theory, measurement, and links to well-being. Journal of Social Clinical Psychology, 19, 43-55. doi: 10.1521/jscp.2000.19.1.43.

McCullough, M. E., Rachal, K. C., Sandage, S. J., Worthington, E. L., Jr., Brown, S. W., \& Hight, T. L. (1998). Interpersonal forgiving in close relationships II: Theoretical elaboration and measurement. Journal of Personality and Social Psychology, 75, 1586-1603. doi: http://dx.doi.org/10.1037/0022-3514.75.6.1586.

Mccullough, M. E., Emmons, R. A., \& Tsang, J. A. (2002). The grateful disposition: a conceptual and empirical topography. Journal of Personality and Social Psychology, 82, 112-127. doi: http://dx.doi.org/10.1037/00223514.82.1.112.

McCullough, M. E., Worthington, E. L., \& Rachal, K. C. (1997). Interpersonal forgiving in close relationships. Journal of Personality and Social Psychology, 73, 321-336.

Palmer, B., Walls, M., Burgess, Z., \& Stough, C. (2001). Emotional intelligence and effective leadership. Leadership \& Organisational Development Journal, 22, 5-10. doi: http://dx.doi.org/10.1108/01437730110380174.

Pavot, W., \& Diener, E. (2008). The Satisfaction with Life Scale and the emerging construct of life satisfaction. The Journal of Positive Psychology, 3, 137-152. doi: 10.1080/17439760701756946.

Rodden, J. (2003). Forgiveness, education, public policy: The road not yet taken. Modern Age, Fall, 333-341.

Rothstein, B., \& Uslaner, E. M. (2005). All for all: Equality, corruption, and social trust. World Politics, 58, 41-72. doi: 10.1353/wp.2006.0022.

Rostami, Z. \& Abedi, M. R. (2012). Does academic burnout predicts life satisfaction or life satisfaction is predictor of academic burnout? Interdisciplinary Journal of Contemporary Research in Business, 3(12), 668-674.

Sapmaz, F. \& Doğan, T.(2012). Optimism as a predictor of happiness and life satisfaction.Mersin University Journal of the Faculty of Education, 8(3), 6369.

Siahpush, M., Spittal, M., \& Singh, G. K. (2008). Happiness and life satisfaction prospectively predict self-rated health, physical health, and the presence of limiting, long-term health conditions. American Journal of Health Promotion, 23, 18-26. doi: 10.4278/ajhp.061023137.

Sobel M. E. (1982). Asymptotic confidence intervals for indirect effects in structural equation models. In S. Leinhardt (Ed.), Sociological methodology (pp. 290-312). Washington DC: American Sociological Association.

Suldo, S. M. \& Huebner, E. S. (2004). Does life satisfaction moderate the effects of stressful life events on psychopathological behavior during adolescence? School Psychology Quarterly, 19, 93-105. doi: http://dx.doi.org/10.1521/scpq.19.2.93.33313.

Tsang, J., \& Stanford, M. (2006). Forgiveness for intimate partner violence: The influence of victim and offender variables. Personality and Individual Differences, 42, 653-664.

Thoresen, C.E., Harris, A.H.S., \& Luskin, F. (2000). Forgiveness and health: An unanswered question. In M.E. McCullough, K.I. Pargament, \& C. 
E. Thoresen (Eds.), Forgiveness: Theory, research, and practice (pp. 254-280). New York: Guilford Press.

Tripp, T. M., Bies, R. J., \& Aquino, K. (2002). Poetic justice or petty jealousy? The aesthetics of revenge. Organizational Behaviour and Human Decision Processes, 89, 966-984. doi: 10.1016/S0749-5978(02)00038-9.

Walker, D. F., \& Gorsuch, R. L. (2002). Forgiveness within the Big Five personality model. Personality and Individual Differences, 32, 1127-1137.
Wong, S. S., \& Lim, T. (2009). Hope versus optimism in Singaporean adolescents: Contributions to depression and life satisfaction. Personality and Individual Differences, 46, 648-652.

Yiğit, R. (2012). Examination of relationship between self-esteem, life satisfaction of riot policemen and their approach to dealing with stress, KEFAD, 13(1), 61-75.

(Article received: 30-08-2014; revised: 08-03-2015; accepted: 14-03-2015) 